\title{
PERANCANGAN VISUALISASI GELOMBANG BERBASIS VBA DENGAN MICROSOFT EXCEL SEBAGAI MEDIA PEMBELAJARAN FISIKA SISWA SMA
}

\author{
Ewis Amalya ${ }^{1}$, M. Rahmad ${ }^{2}$, Syahril $^{3}$ \\ ${ }^{1,2,3)}$ FKIP Universitas Riau \\ e-mail: ewisamalya222@gmail.com \\ m.rahmad@.unri.ac.id \\ lelsyahri177@gmail.com
}

\begin{abstract}
Abstrak
Penelitian ini bertujuan untuk merancang media pembelajaran visualisasi gelombang berbasis VBA pada microsoft excel sebagai media pembelajaran fisika yang valid bagi siswa SMA kelas XI. Penelitian ini menggunakan metode Research and Development dengan tipe ADDIE. Tahap dari perancangan media pembelajaran visulisasi gelombang ini meliputi Analisis, Desain, Pengembangan, Implementasi, dan Evaluasi. Namun, pada penelitian ini peneliti hanya melakukan hingga tahap pengembangan, kemudian dilakukan validasi media menggunakan instrumen penilaian. Instrumen yang digunakan adalah lembar penilaian validasi media pembelajaran visualisasi gelombang berbasis VBA pada Microsoft Excel. Penilaian dilakukan pada 3 aspek yaitu aspek perancangan, aspek isi pembelajaran, dan aspek pedagogik yang dinilai oleh validator. Validator terdiri dari tim pakar dan pengguna. Pakar yaitu validator yang merupakan dosen Pendidikan Fisika Universitas Riau, sedangkan pengguna yaitu validator dari guru SMA yang berada di Pekanbaru. Skor validasi yang didapat untuk aspek perancangan dari pakar dan pengguna 3.62. Skor validasi pada aspek isi pembelajaran dari pakar dan pengguna 3.60, dan skor validasi yang didapat pada aspek pedagogik dari pakar dan pengguna adalah 3.73. Hasil analisis skor validasi media pembelajaran visualisasi gelombang berbasis VBA pada microsoft excel berada pada kategori ST (sangat tinggi) untuk semua aspek yang dinilai. Dengan demikian media ini dapat dikatakan valid dan layak digunakan sebagai media pembelajaran fisika yang valid pada materi gelombang untuk siswa SMA kelas XI.
\end{abstract}

Kata Kunci: media berbasis VBA, validitas, visualisasi gelombang

\begin{abstract}
This research aimed to design wave visualization based VBA on microsoft excel as a valid physics learning media for senior high school students of class XI. This research used Research and Development method with ADDIE type. The steps of the design of learning media of this wave visualization include Analysis, Design, Development, Implementation, and Evaluation. However, in this research the researchers only implement up to the development step, then conducted media validation using assessment instruments. The instrument used is validation sheets of the wave visualization learning media. assessment is done on three aspects, namely design aspect, learning content aspect, and pedagogic aspect assessed by validator. Validator consists of team experts and users. Expert validator is a lecturer of Physics Education University of Riau, while the user is a teachers from senior high school on pekanbaru. The validation score obtained for the design aspect of the experts and users is 3.62. The validation score on aspects of learning content from the experts and users is 3.60 and the validation score obtained on the pedagogic aspect of the experts and users is 3.73. The validation results of wave visualization based VBA on excel is in the category very high for all aspects assessed, thus this media can be valid and feasible to be used as a valid physics learning media of students class XI in senior high school.
\end{abstract}

Keywords : VBA-based media, validity, wave visualization

${ }^{1)}$ Komunikasi Penulis 


\section{Pendahuluan}

Pembelajaran fisika adalah salah satu pembelajaran yang banyak memerlukan media untuk menyampaikan maupun menjelaskan materi. Fisika bukan pelajaran yang hanya terdiri dari konsep-konsep yang berasal dari rumus-rumus saja, terkadang fisika memerlukan pengalaman langsung dari siswa. Salah satu peran media pembelajaran ialah memberikan pengalaman-pengalaman yang tidak bisa diperoleh secara langsung, tetapi dapat disajikan dengan media pembelajaran. Rifqi et al. (2014) menyebutkan bahwa sebagai alat bantu pembelajaran, peran dan fungsi media pembelajaran tidak boleh diremehkan. Sebab proses pembelajaran yang berkualitas selalu menyediakan sumber belajar atau media pembelajaran yang kaya dan bervariasi. Pembelajaran dewasa ini bisa bersumber dari mana saja, banyak sumber yang bisa diperoleh siswa. Seseorang akan lebih mudah mengakses sumber-sumber belajar yang diperlukan. Sistem pendidikan pun akan mengalami perkembangan yang lebih baik dengan bantuan teknologi informasi (Tombade, 2011). Selain media pembelajaran komponen penting lain yang juga berperan dalam menciptakan proses pembelajaran yang baik ialah kualitas guru. Tiara et al. (2013) mengatakan seorang guru fisika dituntut untuk mampu menjelaskan gejala fisika secara fisis, bukan sekedar menuliskan rumusan matematis secara panjang lebar di papan tulis.

Analisis terhadap pembelajaran fisika bagi siswa SMA telah dilakukan oleh Kudang et al. (dalam Amiruddin \& Stefanus, 2015) berdasarkan data dari hasil analisis kuesioner, kemudian dihubungkan dengan daftar produk media pembelajaran fisika yang ada, didapatkan hasil bahwa media pembelajaran gelombang masih terdapat kekurangan dalam aspek visualisasi. Materi gelombang merupakan materi yang sudah didapatkan siswa sejak SMP, hanya saja lebih diperdalam lagi ketika siswa berada di SMA. Materi gelombang memiliki banyak sekali konsep-konsep yang bersifat abstrak dan didapat melalui gambar. Selain itu materi ini memerlukan kemampuan membaca parameter-parameter yang ada, baik dari gambar atau dari parameter yang dibuat dalam bentuk gambar (Amiruddin \& Stefanus, 2015). Rachmad \& Danang (2015) mengatakan, bahwa terdapat beberapa rumus yang harus dihafalkan oleh siswa dalam materi karakteristik gelombang, sementara itu seorang guru fisika dituntut harus mampu menggambar kan gelombang terhadap pengaruh dari parameter-parameternya dengan baik untuk dapat mencapai tujuan pembelajaran sehingga diperlukan media yang bersifat visual. Kemampuan siswa dalam mengidentifikasi dan menginterpretasi konsep-konsep fisika, jelas merupakan prasyarat penting bagi penggunaan konsep-konsep untuk membuat inferensiinferensi yang lebih kompleks atau untuk pemecahan soal fisika yang berkaitan dengan konsep-konsep tersebut (Mohd Jasmi et al., 2014). Visualisasi menggunakan komputer merupakan salah satu media pembelajaran yang mampu merepresentasikan fenomena fisika secara ideal dan dapat melengkapi keterbatasan laboratorium di sekolah.

Salah satu perangkat lunak yang dapat digunakan untuk membuat simulasi fisika adalah microsoft visual basic for application yang terdapat dalam microsoft excel. Salah satu keunggulan dari VBA excel dalam membuat visualisasi dan simulasi gejala fisika, yaitu dapat dilakukan pengaturan variabelvariabel fisis yang dapat disesuaikan dengan kenyataan (Hari et al., 2014). Aplikasi microsoft excel khususnya dibidang fisika dapat digunakan secara efektif untuk membantu komputasi maupun kalkulasi rumus (formulasi) fisika dan menangani data berupa angka (numerik) yang apabila dikerjakan secara manual akan memakan banyak waktu. Kehandalan microsoft excel yang lain adalah excel juga memiliki kemampuan yang sangat baik dalam menampilkan berbagai simulasi, eksperimen fisika secara visual dan konsep matematis yang abstrak (Nurhayati, 2014).

Pembelajaran fisika dengan memanfaatkan microsoft excel telah memberikan hasil yang positif. Song Tae Pak, et al. (dalam Sutardi, 2010) menunjukkan bahwa 70\% guru merasa mendapatkan ide baru pembelajaran dengan memanfaatkan microsoft excel dan $80 \%$ siswa merasa terbantu dalam belajar fisika. Beberapa media pembelajaran menggunakan visualisasi gejala fisika berbasis VBA telah dikembangkan yaitu, Interactive Learning Media for Lenses and Their Applications Using Macro Visual Basic in Microsoft PowerPoint yang dikembangkan oleh Sari et al. (2015), kemudian Simulasi Asas Torricelli Menggunakan Visual Basic for 
Application (VBA) pada Microsoft Excel dikembangkan oleh Dinar et al. (2014). Namun sejauh yang peneliti selidiki, belum menemukan penelitian berbasis VBA dengan microsoft excel pada materi gelombang. Oleh sebab itu, hal ini menjadi salah satu alasan yang menarik bagi peneliti untuk mengembangkan media pembelajaran pada materi karakteristik gelombang mekanik di SMA, kemudian sebagai solusi dari kendalakendala yang ada, sehingga menarik untuk dikembangkan media pembelajaran fisika yang dikemas dalam bentuk "Perancangan visualisasi gelombang berbasis VBA dengan microsoft excel sebagai media pembelajaran fisika bagi siswa SMA"

\section{Bahan dan Metode}

Metode penelitian yang digunakan ialah metode Research and Development (R\&D) yang dikembangkan oleh Borg dan Gall. Pada penilitian ini metode $R \& D$ yang digunakan dengan menerapkan rancangan model ADDIE yang terdiri dari lima tahapan Analisys, Design, Development, Implementation dan Evaluation (Nada Aldoobie, 2015). Tahapan ADDIE dalam kajian yang dilakukan hanya sampai pada langkah pengembangan dan revisi media, dikarenakan dalam kajian ini, hanya sampai pada tahap merancang dan membangun, kemudian dilakukan validasi oleh validator, selanjutnya dilakukan perbaikan atau revisi. Aspek yang dinilai pada tahap validasi, diadaptasi dari kriteria pengembangan media pembelajaran yang ditulis oleh Yuni (2010). Dari segi media aspek-aspek yang dinilai antara lain: aspek perancangan, aspek pedagogik, aspek isi pembelajaran.

Validator dalam penelitian ini adalah dosen Program Studi Pendidikan Fisika yang merupakan ahli dalam bidang media dan materi yang berjumlah 4 orang, serta guruguru fisika yang mengajar di SMA sebanyak 2 orang. Teknik pengumpulan data produk ini dilakukan sebanyak 2 kali validasi. Validasi pertama dilakukan dengan memberikan lembar penilaian pertama kepada validator untuk memberikan saran perbaikan media, setelah dilakukan perbaikan sesuai saran lanjut ke tahap selanjutnya yaitu memberikan lembar penilaian kedua kepada validator. Selanjutnya validator memberikan penilaian terhadap produk sesuai dengan aspek dan indikator yang telah dibuat.

Teknik analisis data yang digunakan dalam penelitian ini adalah teknik analisis deskriptif. Teknik analisis deskriptif ini dilakukan dengan menggunakan statistik deskriptif, yaitu statistik yang bertujuan mendeskripsikan atau menggambarkan data yang telah terkumpul sebagaimana adanya tanpa bermaksud membuat kesimpulan yang berlaku secara umum atau generalisasi (Sugiyono, 2012).

Analisis data hasil uji validitas dilakukan dengan tahapan sebagai berikut:

1. Menjumlahkan nilai untuk tiap indikator lembar penilaian validitas.

Skala penilaian lembar validitas berdasarkan pernyataan yang diberikan oleh validator pada lembar penilaian diperoleh skor berdasarkan kategori menggunakan skala Likert. Kemudian dilakukan penjumlahan untuk tiap indikator penilaian terhadap skor tersebut. Skor 4 untuk pernyataan indikator "Sangat Setuju", 3 untuk pernyataan "Setuju", 2 untuk pernyataan "Tidak Setuju", dan 1 untuk pernyataan "Sangat Tidak Setuju” (Djaali \& Pudji, 2008).

2. Mencari nilai rata-rata tiap indikator yang diberikan oleh validator yang dilakukan setelah menghitung skor pernyataan yang diberikan oleh masing-masing validator.

3. Menentukan kategori nilai rata-rata indikator berdasarkan skala Likert dan menentukan nilai validitas subjek penelitian.

Tabel 1. Cara menentukan nilai validitas subjek penelitian

\begin{tabular}{lll}
\hline Skor Validasi & \multicolumn{1}{c}{ Kategori } & $\begin{array}{l}\text { Kategori } \\
\text { Validitas }\end{array}$ \\
\hline $3,25<\mathrm{V} \leq 4,00$ & $\begin{array}{l}\text { Sangat Tinggi } \\
\text { (ST) }\end{array}$ & Valid \\
$2,50<\mathrm{V} \leq 3,25$ & Tinggi (T) & Valid \\
$1,75<\mathrm{V} \leq 2,50$ & Rendah (R) & Kurang Valid \\
$1,00<\mathrm{V} \leq 1,75$ & Sangat Rendah & Tidak Valid \\
& (SR) & \\
\hline
\end{tabular}

Sumber: Khabibah (dalam Yuni, 2010). 
Perangkat media dikatakan valid apabila semua indikator penilaian berada pada kategori tinggi atau sangat tinggi (T/ST) berdasarkan interval skor validasi pada Tabel 1. Apabila masih ada indikator yang berada pada kategori rendah atau sangat rendah (R/SR) pada salah satu indikator penilaian tersebut, maka akan dilakukan perbaikan pada indikator tersebut dan dilakukan validasi ulang pada indikator tersebut.

\section{Hasil dan Pembahasan}

Hasil perancangan media pembelajaran visualisasi gelombang berbasis VBA pada microsoft excel terdiri dari 2 pertemuan yang sesuai dengan indikator kurikulum 2013. Hasil dari pengembangan media pembelajaran ini adalah visualisasi gelombang dengan menggunakan visual basic pada microsoft excel. Tampilan dapat diatur dengan memasukkan data dari visualisasi agar tampilan sesuai dengan output yang ingin ditampilkan dan beberapa animasi dengan tipe gif yang ditampilkan dengan tampilan microsoft powerpoint.

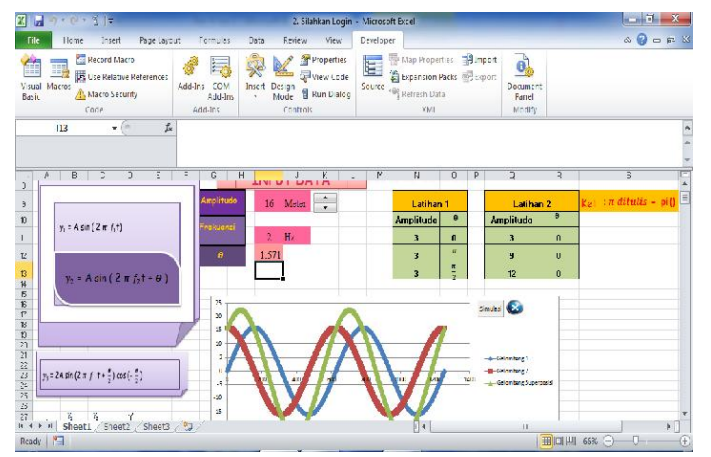

Gambar 1. Tampilan visualisasi.

Gambar 1 merupakan salah satu tampilan dari menu visualisasi interferensi gelombang pada media pembelajaran visualisasi gelombang berbasis VBA dengan microsoft excel. Hasil dari pengembangan media pembelajaran yang menggunakan komputer pada materi gelombang bunyi dan pendengaran dapat mendukung kemandirian siswa dalam pembelajaran (Laifa, 2015). Hasil dari pengembangan media pembelajaran fisika siswa SMA berbasis VBA dapat mendukung kemandirian siswa dalam materi fisika dengan penggunaan gambar bergerak, kemudian dengan data yang harus dimasukkan oleh siswa bertujuan untuk membantu siswa membentuk pengetahuannya sesuai dengan pengalaman pembelajaran pada materi gelombang yang pernah didapatkan di bangku SMP.

Sasmito \& Andjrah (2012) menyebutkan media pembelajaran interaktif yang dilengkapi dengan animasi pada materi sebagai penekanan, serta penggunaan pendekatan visual yang disediakan pada komputer dapat meningkatkan minat dan kreativitas siswa dalam belajar. Media pembelajaran gelombang berbasis VBA ini juga dilengkapi gambar bergerak dengan file bertipe gif yang sudah dimodifikasi oleh pengkaji.

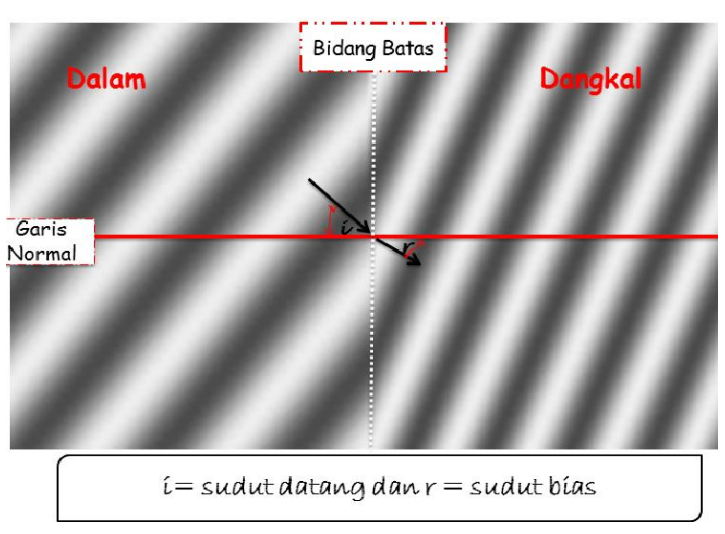

Gambar 2. Peristiwa refraksi gelombang.

Gambar 2 merupakan tampilan materi refraksi gelombang pada media yang telah dimodifikasi oleh peneliti untuk dapat menarik minat dan kreativitas siswa (Rachmat, 2014).

Hasil analisis data validasi media pembelajaran visualisasi yang mengacu pada Tabel 1, diperoleh hasil analisis data pada aspek perancangan visualisasi yang diberikan oleh pakar dan pengguna sebagaimana ditunjukkan pada Tabel 2. Skor terendah yang diberikan oleh pakar pada aspek perancangan yaitu item 2 dengan skor 3.25 terkait kesesuaian huruf, sedangkan item terendah yang diberikan oleh pengguna pada aspek ini yaitu item 5 skor 3.00 terkait kedudukan teks, grafik dan ikon dan item 9 skor 3.00 terkait animasi yang diterapkan. Item-item tersebut sebenarnya dapat dibuat lebih optimal, namun item terkait sudah dalam kategori Tinggi, sehingga item ini tidak dilakukan perubahan. Untuk item lainnya semuanya sudah 
berkategori sangat tinggi sehingga secara keseluruhan berkategori sangat tinggi dengan skor dari Pakar 3.58 dan skor 3.65 dari Pengguna.

Berdasarkan hasil analisis data validasi pada aspek isi pembelajaran didapat hasil seperti yang terdapat pada Tabel 3. Terdapat tujuh item memperoleh skor terendah yang diberikan oleh Pakar yaitu pada item 11 sampai item 17 dengan skor 3.25, sedangkan skor terendah dari Pengguna terdapat pada item 8 skor 3.00. Namun demikian kategori skornya sudah Tinggi. Oleh karena itu, dalam kajian ini item-item tersebut tidak dilakukan perbaikan, karena sudah memenuhi syarat validasi. Item-item lainnya pada aspek isi sudah pada kategori sangat tinggi dengan skor rata-rata oleh Pakar 3.56 dan skor rata-rata dari Pengguna 3.64. Skor validitas media pada aspek isi rata-rata berada pada kategori ST (sangat tinggi) yang artinya aspek isi hasil perancangan media pembelajaran berbasis
VBA dengan microsoft excel ini dinyatakan valid dan layak untuk digunakan.

Hasil analisis data validitas dari aspek pedagogik ditunjukkan pada Tabel 4. Hasil dari uji kelayakan media pada aspek pedagogik oleh Pakar dan Pengguna diproleh skor terendah 3.50 namun sudah berkategori sangat tinggi. Hasil ini berarti bahwa semua item sudah berkategori sangat tinggi. Skor rata-rata dari Pakar yaitu 3.65 dan dari Pengguna diperoleh skor 3.80 .

Hasil penilaian Pakar dan Pengguna terhadap media pembelajaran visualisasi gelombang berbasis VBA dengan microsoft excel, telah memberikan penilaian dari aspek perancangan, isi dan pedagogik yang sudah memenuhi syarat validitas dengan kategori keseluruhan sangat tinggi. Sejalan dengan penelitian yang dilakukan Sari et al. (2015), dimana aspek pedagogik juga mendapatkan skor tertinggi untuk media pembelajaran lensa dan aplikasinya.

Tabel 2 Hasil analisis validitas aspek perancangan oleh pakar dan pengguna

\begin{tabular}{|c|c|c|c|c|c|}
\hline \multirow{3}{*}{ No } & \multirow{3}{*}{ Item } & \multicolumn{4}{|c|}{ Skor Validasi } \\
\hline & & \multicolumn{2}{|c|}{ Pakar } & \multicolumn{2}{|c|}{ Pengguna } \\
\hline & & Rata-rata & Kategori & Rata-rata & Kategori \\
\hline 1. & Desain layar media menarik & 3.75 & ST & 4.00 & ST \\
\hline 2. & $\begin{array}{l}\text { Huruf yang digunakan sesuai dan } \\
\text { mudah dibaca }\end{array}$ & 3.25 & $\mathrm{~T}$ & 3.50 & ST \\
\hline 3. & $\begin{array}{l}\text { Gambar dalam media sesuai } \\
\text { dengan isi }\end{array}$ & 3.50 & ST & 3.50 & ST \\
\hline 4. & $\begin{array}{l}\text { Tombol atau tanda yang } \\
\text { digunakan mudah dikenal }\end{array}$ & 3.75 & ST & 4.00 & ST \\
\hline 5. & $\begin{array}{l}\text { Kedudukan teks, grafis, dan icon } \\
\text { konsisten }\end{array}$ & 3.50 & ST & 3.00 & $\mathrm{~T}$ \\
\hline 6. & $\begin{array}{l}\text { Warna tulisan yang digunakan } \\
\text { sesuai dan mudah dibaca }\end{array}$ & 3.50 & ST & 4.00 & ST \\
\hline 7. & $\begin{array}{l}\text { Gambar yang dibuat membantu } \\
\text { pemahaman siswa }\end{array}$ & 3.75 & ST & 3.50 & ST \\
\hline 8. & $\begin{array}{l}\text { Gambar yang dibuat membantu } \\
\text { pembelajaran }\end{array}$ & 3.75 & $\mathrm{ST}$ & 4.00 & ST \\
\hline 9. & $\begin{array}{l}\text { Animasi yang diterapkan pada } \\
\text { setiap halaman ada penekanan }\end{array}$ & 3.50 & ST & 3.00 & $\mathrm{~T}$ \\
\hline \multirow[t]{2}{*}{10.} & $\begin{array}{l}\text { Ukuran animasi dan tulisan pada } \\
\text { form sesuai }\end{array}$ & 3.50 & ST & 4.00 & ST \\
\hline & Rata-rata & 3.58 & ST & 3.65 & ST \\
\hline
\end{tabular}

Keterangan: $\mathrm{T}=$ Tinggi; $\mathrm{ST}=$ Sangat Tinggi 
Tabel 3 Penilaian validitas aspek isi pembelajaran oleh pakar dan pengguna

\begin{tabular}{|c|c|c|c|c|c|}
\hline \multirow{3}{*}{ No } & \multirow{3}{*}{ Item } & \multicolumn{4}{|c|}{ Skor Validasi } \\
\hline & & \multicolumn{2}{|c|}{ Pakar } & \multicolumn{2}{|c|}{ Pengguna } \\
\hline & & Rata-rata & Kategori & Rata-rata & Kategori \\
\hline 1. & $\begin{array}{l}\text { Kesesuaian antara materi gelombang } \\
\text { dengan media pembelajaran berbasis } \\
\text { visualisasi menggunakan VBA }\end{array}$ & 3.75 & ST & 4.00 & $\mathrm{ST}$ \\
\hline 2. & $\begin{array}{l}\text { Kejelasan konsep gelombang yang } \\
\text { disampaikan pada media pem- } \\
\text { belajaran berbasis visualisasi meng- } \\
\text { gunakan VBA }\end{array}$ & 3.50 & ST & 3.50 & ST \\
\hline 3. & $\begin{array}{l}\text { Kejelasan visualisasi dalam } \\
\text { menyampaikan konsep fisika pada } \\
\text { media pembelajaran berbasis } \\
\text { visualisasi menggunakan VBA }\end{array}$ & 3.75 & ST & 3.50 & ST \\
\hline 4. & $\begin{array}{l}\text { Visualisasi dapat mendeskripsikan } \\
\text { gelombang mekanik }\end{array}$ & 3.50 & ST & 3.50 & ST \\
\hline 5. & $\begin{array}{l}\text { Visualisasi dapat mendeskripsikan } \\
\text { makna gelombang transversal }\end{array}$ & 3.50 & ST & 3.50 & ST \\
\hline 6. & $\begin{array}{l}\text { Visualisasi dapat menjelaskan } \\
\text { puncak gelombang }\end{array}$ & 4.00 & ST & 4.00 & ST \\
\hline 7. & $\begin{array}{l}\text { Visualisasi dapat menjelaskan dasar } \\
\text { gelombang }\end{array}$ & 3.75 & ST & 4.00 & ST \\
\hline 8. & $\begin{array}{l}\text { Visualisasi dapat menjelaskan } \\
\text { panjang gelombang }\end{array}$ & 3.75 & ST & 3.00 & $\mathrm{~T}$ \\
\hline 9. & $\begin{array}{l}\text { Visualisasi menjelaskan amplitudo } \\
\text { gelombang }\end{array}$ & 4.00 & ST & 3.50 & ST \\
\hline 10. & \begin{tabular}{llr} 
Visualisasi & \multicolumn{1}{c}{ dapat } & menjelaskan \\
pengaruh & perubahan & amplitudo \\
terhadap & peristiwa & interferensi \\
gelombang & &
\end{tabular} & 3.75 & $\mathrm{ST}$ & 4.00 & ST \\
\hline 11. & $\begin{array}{l}\text { Visualisasi dapat menjelaskan } \\
\text { pengaruh perubahan sudut terhadap } \\
\text { gelombang superposisi pada } \\
\text { peristiwa interferensi gelombang }\end{array}$ & 3.25 & $\mathrm{~T}$ & 3.50 & ST \\
\hline 12. & $\begin{array}{l}\text { Visualisasi dapat menjelaskan cara } \\
\text { menghitung frekuensi pada } \\
\text { gelombang transversal }\end{array}$ & 3.25 & $\mathrm{~T}$ & 3.50 & ST \\
\hline 13. & $\begin{array}{l}\text { Visulisasi dapat mendeskripsikan } \\
\text { makna gelombang longitudinal }\end{array}$ & 3.25 & $\mathrm{~T}$ & 3.50 & ST \\
\hline 14. & $\begin{array}{l}\text { Visualisasi dapat menjelaskan } \\
\text { rapatan pada gelombang longitudinal }\end{array}$ & 3.25 & $\mathrm{~T}$ & 3.50 & ST \\
\hline 15. & $\begin{array}{llr}\text { Visualisasi } & \text { apat } & \text { menjelaskan } \\
\text { regangan } & \text { pada } & \text { gelombang } \\
\text { longitudinal } & & \end{array}$ & 3.25 & $\mathrm{~T}$ & 3.50 & ST \\
\hline 16. & $\begin{array}{l}\text { Simulasi dapat menjelaskan cara } \\
\text { menghitung frekuensi } \\
\text { gelombang longitudinal }\end{array}$ & 3.25 & $\mathrm{~T}$ & 3.50 & ST \\
\hline 17. & $\begin{array}{l}\text { Animasi dapat mendeskripsikan } \\
\text { contoh-contoh gelombang longi- } \\
\text { tudinal }\end{array}$ & 3.25 & $\mathrm{~T}$ & 4.00 & ST \\
\hline 18. & $\begin{array}{l}\text { Visulisasi dapat mendeskripsikan } \\
\text { peristiwa pemantulan gelombang } \\
\text { pada ujung tetap }\end{array}$ & 3.75 & ST & 3.50 & ST \\
\hline 19. & $\begin{array}{l}\text { Visulisasi dapat mendeskripsikan } \\
\text { peristiwa pemantulan gelombang } \\
\text { pada ujung bebas }\end{array}$ & 3.75 & ST & 4.00 & ST \\
\hline 20. & $\begin{array}{l}\text { Visualisasi dapat mendeskripsikan } \\
\text { peristiwa pembiasan gelombang }\end{array}$ & 3.75 & ST & 4.00 & ST \\
\hline
\end{tabular}




\begin{tabular}{llcccc}
\hline \multirow{2}{*}{ No } & \multirow{2}{*}{ Item } & \multicolumn{3}{c}{ Skor Validasi } \\
\cline { 3 - 6 } & & \multicolumn{2}{c}{ Pakar } & \multicolumn{2}{c}{ Pengguna } \\
\cline { 3 - 6 } 21. & $\begin{array}{l}\text { Visualisasi dapat mendeskripsikan } \\
\text { peristiwa difraksi gelombang }\end{array}$ & 3.50 & ST & 3.50 & ST \\
22. & $\begin{array}{l}\text { Visualisasi dapat mendeskripsikat } \\
\text { peristiwa interferensi gelombang }\end{array}$ & 3.50 & ST & 3.50 & ST \\
\hline & Rata-rata & 3.56 & ST & 3.64 & ST \\
\hline
\end{tabular}

Keterangan: $\mathrm{T}=$ Tinggi $; \mathrm{ST}=$ Sangat Tinggi

Tabel 4 Penilaian validitas aspek pedagogik oleh pakar dan pengguna

\begin{tabular}{|c|c|c|c|c|c|}
\hline \multirow{3}{*}{ No } & \multirow{3}{*}{ Item } & \multicolumn{4}{|c|}{ Skor Validasi } \\
\hline & & \multicolumn{2}{|c|}{ Pakar } & \multicolumn{2}{|c|}{ Pengguna } \\
\hline & & Rata-rata & Kategori & Rata-rata & Kategori \\
\hline 1. & $\begin{array}{l}\text { Animasi yang disajikan dalam } \\
\text { media pembelajaran berbasis } \\
\text { visualisasi menggunakan VBA } \\
\text { sesuai dengan karakteristik } \\
\text { siswa SMA kelas XI }\end{array}$ & 3.50 & ST & 3.50 & ST \\
\hline 2. & $\begin{array}{l}\text { Konsep-konsep gelombang } \\
\text { transversal yang disampaikan } \\
\text { dalam media mudah dipahami }\end{array}$ & 3.75 & ST & 4.00 & ST \\
\hline 3. & $\begin{array}{l}\text { Konsep-konsep gelombang } \\
\text { longitudinal yang disampaikan } \\
\text { dalam media mudah dipahami }\end{array}$ & 3.75 & ST & 3.50 & ST \\
\hline 4. & $\begin{array}{l}\text { Penyampaian topik menarik } \\
\text { perhatian siswa SMA kelas XI }\end{array}$ & 3.50 & ST & 4.00 & ST \\
\hline 5. & $\begin{array}{l}\text { Kalimat yang digunakan } \\
\text { mudah dipahami siswa SMA } \\
\text { kelas XI }\end{array}$ & 3.75 & ST & 4.00 & ST \\
\hline & Rata- rata & 3.65 & ST & 3.80 & ST \\
\hline
\end{tabular}

Keterangan: $\mathrm{ST}=$ Sangat Tinggi

Tabel 5 Kategori validitas setiap aspek oleh pakar dan pengguna

\begin{tabular}{|c|c|c|c|c|c|c|c|}
\hline \multirow{2}{*}{ No } & \multirow{2}{*}{ Aspek } & \multicolumn{2}{|c|}{ Pakar } & \multicolumn{2}{|c|}{ Pengguna } & \multirow{2}{*}{$\begin{array}{l}\text { Skor } \\
\text { Rerata }\end{array}$} & \multirow{2}{*}{$\begin{array}{l}\text { Kategori } \\
\text { Validitas }\end{array}$} \\
\hline & & Nilai & Kategori & Nilai & Nilai & & \\
\hline 1. & Perancangan & 3.58 & ST & 3.65 & ST & 3.62 & Valid \\
\hline 2. & Isi Pembelajaran & 3.56 & ST & 3.64 & ST & 3.60 & Valid \\
\hline 3. & Pedagogik & 3.65 & ST & 3.80 & ST & 3.73 & Valid \\
\hline
\end{tabular}

Keterangan: $\mathrm{ST}=$ Sangat Tinggi

Tabel 5 memperlihatkan bahwa nilai tertinggi berada pada aspek pedagogik. sedangkan aspek isi pembelajaran masih mendapatkan skor terendah dibandingkan ketiganya. Nilai rata-rata yang diperoleh 3.70, yaitu berada pada kategori sangat tinggi.

Berdasarkan Tabel 5 diketahui bahwa hasil perancangan media pembelajaran 
visualisasi gelombang berbasis VBA dengan microsoft excel mendapatkan penilaian dari Pakar dan Pengguna pada aspek perancangan, isi, dan pedagogik berkategori sangat tinggi secara keseluruhan, sehingga ketiga aspek penilaian dinyatakan valid. Hasil tersebut juga didukung oleh kajian Hari et al. (2014) tentang simulasi asas Torricelli berbasis VBA dengan microsoft excel berada pada kategori valid untuk aspek perancangan, isi, dan pedagogik.

Keunggulan media visualisasi gelombang yang dirancang ini adalah siswa SMA dapat lebih mudah memahami dan mempelajari konsep gelombang melalui perangkat media berbasis ICT dengan berbagai konsep dalam bentuk teks, gambar atau grafik, dan animasi. Selain itu siswa juga dapat mempelajari kembali dirumah atau dimana saja jika aplikasi media sudah diberikan programnya, sehingga dapat dibuka melalui laptop atau notebook. Keunggulan lainnya melalui media ini, guru lebih berperan sebagai fasilitator dan lebih menudahkan guru dalam membelajarkan konsep gelombang pada siswa yang mengikuti pembelajaran konsep gelombang.

Media visualisasi gelombang ini baru pada tahap validasi oleh pakar dan pengguna (Guru), sehingga masih perlu dikembangkan supaya lebih baik lagi melalui uji empiris dalam skala kecil atau skala luas, untuk menghasilkan media yang dapat bermanfaat bagi pengembangan pengetahuan khususnya dalam bidang fisika.

\section{Kesimpulan dan Saran}

Berdasarkan hasil dan pembahasan dari penelitian ini, maka dapat disimpulkan bahwa perancangan visualisasi gelombang berbasis VBA dengan microsoft excel sebagai media pembelajaran fisika siswa SMA secara keseluruhan memperoleh kategori sangat tinggi, baik pada aspek perancangan, aspek isi pembelajaran, maupun aspek pedagogik oleh pakar dan pengguna. Dengan demikian hasil perancangan visualisasi gelombang berbasis VBA dengan microsoft excel yang telah dibuat dinyatakan valid dan layak digunakan sebagai media pembelajaran fisika bagi siswa SMA yang sesuai dengan tuntutan kurikulum 2013.

Pengembangkan media dalam kajian ini hanya pada tahap pembuatan visualisasi untuk materi gelombang yang divalidasi oleh pakar (dosen) dan pengguna (guru fisika SMA yang berada di Pekanbaru). Untuk kajian selanjutnya, direkomendasikan melakukan: 1) Uji validitas secara empiris media visualisasi gelombang berbasis VBA dengan microsoft excel yang telah dirancang, 2) Memperbaiki tampilan media yang masih berupa microsoft excel dengan menggunakan VBA, 3) Membuat media berbasis VBA dengan microsoft excel pada materi fisika lainnya.

\section{Daftar Pustaka}

Amiruddin \& Stefanus, 2015. Sistem Pembelajaran Berbasis LTSA Materi Gelombang dan Sifat-sifatnya dengan Metode Problem Solving. Jurnal Teknologi Informasi. 6 (1).

Dinar M. F., Hari Anggit Cahyo Wibowo, \& Widya Arisya Putri, 2014. Simulasi Asas Torricelli Menggunakan Visual Basic For Application (VBA). Prosiding Simposium Nasional Inovasi Pembelajaran dan SAINS (SNIPS 2014) 1011 Juni 2014, Bandung.

Djaali \& Pudji Muljono, 2008. Pengukuran dalam Bidang Pendidikan. Program Pasca Sarjana: UNJ, Jakarta.

Hari Anggit Cahyo Wibowo, Dinar Maftukh Fajar, \& Widya Arisya Putri, 2014. Pembuatan Simulasi Fisika Gerak Partikel dalam Selektor Kecepatan. Prosiding Simposium Nasional Inovasi Pembelajaran dan SAINS (SNIPS 2014) 10-11 Juni 2014, Bandung.

Laifa Rahmawati, 2015. Pengembangan Media Pembelajaran Berbasis Komputer untuk Mendukung Kemandirian Belajar Siswa SMP. Jurnal Fisika dan Pendidikan Fisika, 1(2), 22. FKIP Universitas Ahmad Dahlan, Yogyakarta.

Mohd Jasmi, A.R., M. Arief Ismail, \& M. Nasir, 2014. Development and Evaluation of the Effectiveness of Computer-Assisted Physics Instruction. International Education Studies, 7(31), 56. (Online). Diakses 8 Oktober 2017)

Nada Aldoobie, 2015. ADDIE MODEL. American International Journal of Contemporary Research, 5 (6). (Online). $\mathrm{http} / / / \mathrm{www}$.aijcrnet.com/journals/5(6) 
December 2015/10.pdf (diakses 8 Oktober 2017).

Nurhayati, 2014. Penggunaan Media Animasi Berbasis Visual Basic (VBA) Spread sheet Excel untuk Meningkatkan Penguasaan Konsep Mahasiswa pada Materi Osilator Harmonik Sederhana. Jurnal Edukasi Matematika dan Sains, 3 (1).

Rifki F.K., Supurwoko, \& Daru Wahyuningsih, 2014. Pengembangan Media Pembelajaran Ular Tangga Fisika untuk Siswa SMP/Mts Kelas VIII. Jurnal Pendidikan Fisika (Online). FKIP Universitas Sebelas Maret Surakarta.

Rachmad J.S., \& Danang Tandyonomanu, 2015. Pengembangan Media Komik Pembelajaran Mata Pelajaran Ipa Materi Getaran, Gelombang, dan Bunyi Untuk Siswa Kelas VIII Smp Negeri 1 Gedangan. Seminar Nasional Pascasarjana. FMIPA UNESA, Surabaya.

Rachmat, A. Syukur, 2014. Gelombang mekanik. Tempatnya belajar fisika SMA. (online) (diakses 12 Mei 2017).

Sari Sami Novita, Siti Nurul Khotimah, \& Wahyu Hidayat, 2015. Interactive Learning Media for Lenses and Their Applications Using Macro Visual Basic in Microsoft PowerPoint. Prosiding Simposium Nasional Inovasi dan Pembelajaran Sains 2015 (SNIPS 2015) 8 dan 9 Juni 2015, Bandung.

Sasmito \& Andjrah, H.I., 2012. Perancangan Media Interaktif IPA untuk Siswa Kelas
4 SD dengan Metode Learning The Actual Object. Jurnal SAINS dan Seni ITS. 1(1) (Online). http://jits. Perancangan-mediainteraktif-/15803/ iss $3 / 2$ (diakses 8 Oktober 2017).

Sugiyono, 2012. Metode Penelitian Kuantitatif Kualiatatif dan $R \& D$. Alfabeta CV. Bandung.

Sutardi, 2010. Pengembangan Bahan Ajar Fisika SMA Berbasis Spreedsheet untuk Meningkatkan Kemampuan Siswa Berkomunikasi Ilmiah. Prosiding Petemuan Ilmiah XXIV HFI Jateng \& DIY, 10 April 2010 hal 168-179. Semarang.

Tiara Intan Cahyaningtyas, Sulur, \& Heriyanto, 2013. Pengembangan Media Pembelajaran Mandiri dengan Pendekatan Mobile Learning Pokok Bahasan Getaran Gelombang SMP Kurikulum 2013. Skripsi tidak dipublikasikan. Universitas Negeri Malang, Malang.

Tombade, Popat S., 2011. Use of Spreadsheet for the Pertubation Theory in Quantum Harmonic Oscillator. European Journal of Applied Sciences (Online). 3(4). (diakses 28 april 2017).

Yuni Yamasari, 2010. Pengembangan Media Pembelajaran Matematika Berbasis ICT yang Berkualitas. Seminar Nasional Pascasarjana ke X. 4 Agustus 2010. FMIPA UNESA. Surabaya. 